\title{
Estudo anatômico das inserções distais do tendão extensor longo do polegar
} Anatomical studies of the distal insertion of the extensor pollicis longus

\author{
Mauríclo Benedito Ferreira Caetano ${ }^{1}$, Walter Manna Albertoni ${ }^{2}$, Edie Benedito Caetano ${ }^{3}$
}

\section{RESUMO}

Registramos pelo presente estudo que o músculo (ELP) e seu tendão apresentaram poucas variações anatômicas. Não registramos a presença de tendões acessórios e nem a ausência desse músculo ou de seu tendão. Verificamos em todas as preparações a passagem do tendão pelo terceiro compartimento osteofibroso, cruzando sobre os extensor radial curto (ERCC) e longo (ERLC) do carpo e dirigindose ao polegar. A alteração no trajeto tendinoso, desviando-se no sentido radial foi verificada em uma das preparações (1,6\%). A duplicação parcial do tendão proximal a articulação metacarpofalângica (AMFP) foi verificada em 3 observações $(4,8 \%)$, sendo 1 bilateral, e distal à articulação em 5 (8,3\%), 2 bilateralmente. A inserção óssea na base da falange distal (BFD) foi encontrada em todas as observações. Durante sua passagem pela articulação metacarpofalângica, registramos sua inserção na cápsula articular em 14 observações (23,3\%), porém não registramos a inserção óssea nesse local.

O padrão mais comum em relação ao músculo ELP foi a presença constante de 1 tendão, passando pelo terceiro compartimento osteofibroso dorsal do punho com inserção óssea na base da falange distal do polegar.

Descritores: Tenossinovite; Antebraço; Polegar.

\section{INTRODUÇÃO}

Na superfície dorsal do punho encontramos um espessamento da fáscia posterior do antebraço denominado retináculo dos tendões extensores. Este constitui o teto de seis compartimentos por onde passam os tendões extensores. À medida que este retináculo corre obliqüamente, da borda lateral do rádio para a borda medial processo estilóide da ulna e ossos piramidal e pisiforme, ele envia septos que se prendem aos ossos subjacentes formando seis compartimentos por onde passam os tendões extensores ${ }^{(5)}$.

Em cada compartimento os tendões são protegidos por uma bainha sinovial que tem a função de diminuir o atrito durante a excursão dos tendões pelos túneis osteofibrosos.

Uma variação anatômica comum ocorre no primeiro compartimento por onde passam normalmente os tendões abdutor longo do pole-

\section{SUMMARY}

We recorded with this study that the EPL_muscle and its tendon show a few anatomical variations. Any accessories tendons either the absence of this muscle or its tendon was found. In all preparation the passage of the tendon through the third osteofibroses compartment, crossing on the ERBC and ERLC going to the thumb was seen. The change of the tendinuous trajectory, deviating itself to the radial direction in one of the preparations was checked $(1,6 \%)$. The partial duplication of the proximal tendon to the metacarpophalangeal joint (AMP) was seen in three observations (4,8\%), one bilateral and distal to the articulation in five (8,3\%), 2 bilaterally. The bone insertion at the base of distal (BFD) phalanx in all observations were found. During its passage through metacarpophalangeal joint we recorded its insertion in the joint capsule in 14 observations (23,3\%), however the bone insertion there was not observed in this place.

The most common pattern about this (EPL) extensor pollicis longus muscle was the presence of a tendon, passing through the osteofibroses dorsal of wrist compartment with a bone insertion at the base of distal pollicis phalanx.

Key words: Extensor pollicis longus; Anatomical variations; Distal insertions.

\section{INTRODUCTION}

On the dorsal surface of the wrist, we found a thick part of the front forearm fasciae called extensor tendon of the retinaculum. It is responsible for the six compartments where the extensor tendons pass through. As the retinaculum runs obliquely, from the side edge of the radial to the medial edge of the styloid ulna process and pyramidal and piriformis bones, it sends septas which join the underlying bones making six compartments where the extensor tendons pass through ${ }^{(5)}$.

In each compartment the tendons are protected with synovial sheath which has the function of decreasing friction during the passage of the tendons through the osteofibroses tunnels.

A common anatomical variation occurs in the first compartment where the tendon of abductor longus and the tendon of extensor pollicis brevis normally pass through, can have the synovial sheath and compartments separated increasing, then the numbers of compartments from six to seven ${ }^{(6)}$.
Trabalho realizado na Faculdade de Ciências Médicas e Biológicas da
Pontifícia Universidade Católica de São Paulo - Campus Sorocaba

1 - Médico Assistente do Serviço de Cirurgia da Mão da PUC-SP. Mestre em Ortopedia e Traumatologia pela Unifesp - EPM.

2 - Professor Titular. Chefe do Departamento de Ortopedia e Traumatologia da Unifesp - EPM.

3 - Professor Titular. Chefe da Disciplina de Ortopedia e Traumatologia da PUC - SP

Endereço para correspondência: Rua Moóca, 271. CEP: 18040-700 -

Sorocaba - SP - Tel: 012-2329066 / 2113416 - e-mail:

ediecaetano@uol.com.br / mbfc@directnet.com.br

Trabalho recebido em 28/07/03. Aprovado em 09/04/04.
Work performed in the Laboratory of Anatomy of the Medical and Biological Science College of Potifícia Católica University of São Paulo - Campus Sorocaba.

1 - Doctor Assistant of the Hand Surgery Service of PUC -SP, Master in Orthopedics and Traumatology of Unifesp - EPM 2 - Chairman. Head of the Orthopedics and Traumatology Department of Unifesp- EPM

3 - Chairman - Head of the Orthopedics and Traumatology Discipline of PUC - SP

Adress: Rua Móoca, 217 CEP: 18040-700 - Sorocaba - SP - Phone: 012. 2329066 /2113416 - e-mail: ediecaetano@uol.com.br / mbfc@directnet.com.br 
gar (ALP) e extensor curto do polegar (ECP), os quais podem ter bainha sinovial e compartimentos separados elevando assim o total de seis para sete compartimentos(6)

Encontramos com grande freqüência na literatura estudos ${ }^{(3,5,6,8,13)}$ sobre as variações anatômicas dos tendões do primeiro compartimento em virtude do interesse que desperta pela ocorrência freqüente de traumatismos cumulativos desencadeados por esforços repetitivos, como por processos inflamatórios diversos, cujo mais comum e incapacitante é a tenossinovite estenosante de De Quervain.

No entanto, nos tratados clássicos de Anatomia e nas revistas especializadas encontramos poucos relatos sobre as variações do tendão do músculo ELP, principalmente em relação as suas inserções distais.

O tendão do ELP atravessa o terceiro compartimento osteofibroso passando por um sulco sobre o rádio medialmente ao tubérculo de Lister, cruza os extensores radiais longo e curto do carpo do lado ulnar para o radial, formando o limite medial da tabaqueira anatômi$\mathrm{ca}^{(13)}$.

Em situações patológicas como, por exemplo, na artrite reumatóide, o tendão perde a proteção pela sua bainha sinovial, que é acometida pela doença, e sem essa proteção o atrito constante pela sua passagem no canal osteofibroso acarreta a ruptura do tendão e um déficit funcional importante na mão. O mesmo pode ocorrer nas fraturas do rádio distal onde as irregularidades ósseas causadas ao nível do tubérculo de Lister podem levar a ruptura do tendão.

Nosso objetivo neste trabalho foi analisar as variações anatômicas do tendão ELP em sua passagem pelo terceiro compartimento, assim como os locais anatômicos onde ocorrem suas inserções distais.

\section{MATERIAL E MÉTODOS}

O material de estudo desse trabalho é constituído por 60 peças anatômicas correspondentes a 30 pares de membros superiores de cadáveres, nos quais foram dissecados o antebraço distal, o punho e a mão.

A pesquisa foi realizada no laboratório de Anatomia da Faculdade de Ciências Médicas e Biológicas da Pontifícia Universidade Católica de São Paulo - Campus Sorocaba.

Das 60 peças, 20 correspondem a 10 cadáveres frescos conservados em refrigerador e 40 peças correspondem a 20 cadáveres, os quais foram preparados previamente por injeção de formol a 10\% (4 litros) e glicerina em quantidade de 1 litro na artéria femoral.

Os membros dissecados pertenciam a indivíduos com idade variando entre 23 e 67 anos. Escolhemos o material homogêneo para realizar esse trabalho, todos os cadáveres eram da raça branca e pertenciam ao sexo masculino.

Os cadáveres foram colocados em mesa de dissecção, na posição de decúbito dorsal com o membro superior sobre uma prancha de madeira em posição de médio prono-supinação do antebraço.

A dissecção obedeceu a seguinte ordem:

Iniciava-se por uma incisão transversa distal à articulação interfalângica do polegar. Outra incisão transversa foi realizada ao nível da transição dos terços médio e distal do antebraço, acima da junção miotendínea dos músculos a serem dissecados.

Os centros dessas duas incisões transversas foram unidos por uma incisão longitudinal que passava pelo ponto médio entre o tubérculo de Lister e o processo estilóide do rádio. Desta forma dois retaIhos foram levantados e rebatidos um em sentido ventral e outro dorsal. Os ramos sensitivos do nervo radial e a artéria cefálica com seus ramos foram dissecados e removidos.
We very often found in the literature ${ }^{(3,5,6,8,13)}$ studies about anatomi$\mathrm{cal}$ variations of tendon of the first compartment which is a frequent interest in the occurrence of cumulative traumatism developed by repetitive efforts, as well as for several inflammatory process, being the De Quervain tenosynovitis the most common

However, we found in the classical anatomy dissertation and specialized magazines a few articles about the variation of the tendon of the muscle (EPL), especially about its distal insertions.

The tendon of EPL crosses the third osteofibroses compartment passing by a sulcus on the radialis medially to the tubercle of Lister, then crosses the extensors carpis longus and brevis from the ulnar to the radialis side, forming a medial limit of the Anatomical shape ${ }^{(13)}$

About pathological situations such as, rheumatoid arthritis, the tendon loses its protection for the synovial seath, which is accessed by the sickness, besides, without this protection the constant friction due to its passage to the osteofibroses canal cause the broke of the tendon and also loses an important function of the hand. The same can occur in the distal radialis broke where the irregularities of the bones caused at the level of the Tubercle of Lister can lead to the broken tendon.

The objective of this writing was to analyze the anatomical variations of the tendon (EPL) during its trajectory to the third compartment as well as the anatomical place where the distal insertion happens.

\section{MATERIAL AND METHOD}

The study material of this work is made of 60 anatomical pieces corresponding to 30 pairs of upper and lower extremities from human cadavers, from which distal forearm , wrist and hand were dissected.

This research was done in the Laboratory of Anatomy of the Medical and Biological Science College of Potifícia Católica University of São Paulo - Campus Sorocaba.

From the 60 pieces, 20 corresponds to 10 fresh human cadavers kept in the refrigerator, and 40 pieces corresponds to 20 human cadavers which were prepared with formaldehyde injection at 10\% (4 liters) and glycerin having 1 liter amount. in the femoral artery.

The dissected upper limbs belonged to individuals whose age ranging from 23 to 67. Homogenous material was chosen to make this work, all the human cadavers were from the white race and all were male.

The human cadavers were put on a table for dissection, in dorsiduct position with the upper limb resting on a wooden board in position of medium prone supination of the forearm.

The dissection followed these steps:

It started with distal transverse incision to the interphalangeal. thumb Another transverse incision was made at the transition level of medium and distal thirds of the forearm, above the joint of the myotendinous of the muscles to be dissected.

The center of these two transverse incisions were bound with a longitudinal incision that passed through the medium point between the Tubercle of Lister and the styloid radialis process. Thus, two pieces were suspended undercut, one in a ventral direction and the other in a dorsal direction. The sensitive branches of the radialis nerve and the cephalic artery with its branches dissected and removed.

We start the identification of the muscles with the first osteofibroses tunnel. The EPB, APL and EPL muscles were dissected from the myotendinuous to their insertion compartments.

The anatomic variation presence such as the presence of the tendons accessories, absence of tendons, duplification of the tendons, alterations in their trajectory were observed and taken note. The distal tendon insertion was precisely verified and many times with the help of a magnifying made it twice bigger, because in some situations it was difficult to know exactly where the tendon insertion was. 
Iniciamos a identificação dos músculos pelo primeiro túnel osteofibroso. Os músculos ECP, ALP e ELP foram dissecados desde a junção miotendínea até suas inserções.

A presença de variações anatômicas como a presença de tendões acessórios, ausência de tendões, duplicação dos tendões, alterações no trajeto foram observadas e anotadas. A inserção distal do tendão foi verificada minuciosamente e muitas vezes com auxílio de lupa com aumento de 2 vezes, pois em algumas situações encontramos dificuldade para saber exatamente o local de inserção do tendão.

\section{RESULTADOS}

As fibras musculares do músculo ELP convergem para um tendão aplanado, que atravessa o terceiro canal osteofibroso, formado pelo retináculo dos extensores e por um sulco sobre o rádio medialmente ao tubérculo de Lister, cruza os extensores radiais longo e curto do carpo do lado ulnar para o radial, formando o limite medial da tabaqueira anatômica.

Nos 60 membros dissecados não encontramos nenhuma variação anatômica em relação à passagem desse tendão pelo terceiro compartimento osteofibroso, nem o prolongamento do corpo muscular desse tendão até o nível do terceiro canal. Não evidenciamos a presença de tendões acessórios do ELP passando pelo terceiro ou qualquer outro compartimento extensor, também não verificando sua ausência nas dissecções.

Quanto à espessura desse tendão encontramos pequenas variações, porém sem grande importância sob o ponto de vista anatômico ou clínico. Em relação ao trajeto do tendão encontramos apenas em uma observação unilateral (lado direito), em que o tendão após passar pelo terceiro canal osteofibroso inclinava-se em direção radial acompanhando os tendões dos músculos ALP e ECP, de modo a não formar de maneira habitual a tabaqueira anatômica (figs. 1 e 2).

Um fato interessante que observamos foi a duplicação do tendão em sua passagem sobre o dorso do primeiro metacarpiano. $O$ tendão duplicava-se alguns centímetros distal à sua passagem pelo terceiro compartimento osteofibroso e voltava a se unir antes de alcançar a articulação metacarpofalângica. Tal fato foi verificado em 3 peças $(4,8 \%)$, sendo um caso bilateral (fig. 3 ).

Em uma peça anatômica $(1,6 \%)$ correspondente a mão direita de um cadáver, o tendão do músculo ELP duplicava-se $3 \mathrm{~cm}$ proximal à articulação metacarpofalângica do polegar, o mesmo ocorrendo com o tendão do músculo ECP. Os componentes ou expansões dos dois tendões que dirigiam-se ao centro da articulação se uniam e inseriam-se ao nível da articulação metacarpofalângica. Os dois componentes ou expansões laterais cruzavam a articulação metacarpofalângica e dirigiam-se para se inserir na base da falange distal (fig. 4).

Ao nível da articulação metacarpofalângica as fibras aponeuróticas dos músculos abdutor curto do polegar (ACP) lateralmente e adutor do polegar (AP) medialmente inserem-se nos tendões ELP e ECP, mantendo os tendões extensores centrados sobre a articulação metacarpofalângica (fig. 5).

Com referência à inserção do tendão do músculo ELP na base da falange proximal do polegar, encontramos essa na cápsula articular em 14 casos (23,3\%), porém não verificamos a inserção óssea do ELP na base da falange proximal (BFP) (fig. 6)

Ao passar pela articulação metacarpofalângica o tendão alargase e alcança a inserção na base da falange distal. Em todas as peças verificamos que ocorreu a inserção óssea do ELP na base da falange distal (fig. 7).

\section{RESULTS}

The muscular fibers of the EPL converge to a flatted tendon, which crosses the third osteofibroses canal, formed by the extensor of the retinaculum and the sulcus on the radialis medially to the tubercle of Lister, crossing long and short radialis of carpum from the ulnar to the radial side, forming a medial limit of the anatomical shape.

In the 60 upper and lower limbs dissected any anatomical variation in relation to the passage of this tendon through the third osteofibroses compartment was not found, nor the extension of muscular body of this tendon till the level of the third canal. The presence of accessory tendon of the EPL passing through the third or any other extensor compartment were found, neither its absence during the dissection.

About the variation of the thickness of this tendon a few variations were found, however with no great importance from the anatomical or clinical view. About the trajectory of the tendon was found only in a lateral observation ( right side), that the tendon after passing through the third osteofibroses canal bent towards the radialis following the tendons of the APL and EPD muscles in order not to make in a usual way to the anatomical shape. (figure 1 and 2).

The tendon duplication in a passage on the dorsal of the first metacarpals was observed. The tendon duplicated some distal centimeters to its passage by the third osteofibroses compartment and joined again before reaching the metacarpophalangeal joint This fact was detected in three pieces (4.8\%), and one bilateral case (fig.3).

In a anatomical piece $(1,6 \%)$ corresponds to the right hand of a human cadavers, the tendon of EPL muscles duplicated into 3 centimeters proximal to the pollicis metacarpophalangeal, the same happening to the tendon of EPB muscle. The components and expansion of the two tendons drove themselves to the center of the articulation binding and inserting each other at the level of metacarpophalangeal joint. The two components and the expansions crossed the metacarpophalangeal joint and drove in order to insert themselves to the base of the distal phalanx (figure 4)

At the level of metacarpophalangeal joint. The aponeurotic fibers of the muscles of the abductor pollicis brevis (APB) laterally and the abductor pollicis (AP) medially insert them to the tendon of (EPL) and $(E P B)$, maintaining the tendons extensors centered on the metacarpophalangeal joint (fig. 5).

About the insertions of the tendon (EPL) muscle at the base of proximal pollicis phalanx, we found it in joint capsule in 14 cases (23,3\%), however we did not check the bone insertion of the long extensor at the base of the proximal phalanx (fig 6).

When passing through the metacarpophalangeal joint the tendon stretched and reached the insertion at the base of the distal phalanx. In all pieces we noticed the bone insertion of the (EPL) along the base of the distal phalanx (fig 7).

Among 5 observations (8,3\%), two bilaterally, we found the tendon of the EPL muscle duplicated distally to the metacarpophalangeal articulation and inserting itself separately at the base of distal phalanx (figure 8).

Among other three dissected pieces (4,8\%) all unilaterally, one at the left side and the two others at the right side., we found a tendinous bound joining the of the tendons pollicis abductor to the (EPL) next to the insertion of the distal phalanx (figure 9).

At most observations we found the tendon of the EPL muscle thicker than the tendon of the EPB, however in some observations, the thickness between them was exaggeratedly disproportional (figure 10). In some cases they had the same thickness, however in any of the preparations was note the dominance of the thickness of the tendon $E P B$ in relation to EPL. The asymmetric among the antimeres was recorded in 13 cases $(21,6 \%)$ 
Em 5 observações (8,3\%), duas bilateralmente, encontramos o tendão do músculo ELP duplicado distalmente à articulação metacarpofalângica e inserindo-se separadamente na base da falange distal (fig. 8).

Em outras 3 peças dissecadas (4,8\%) todas unilateralmente, sendo uma do lado esquerdo e 2 do direito, encontramos um vínculo tendinoso unindo os tendões dos músculos adutor do polegar ao tendão ELP próximo à sua inserção na falange distal (fig. 9).

Na maioria das observações encontramos o tendão do músculo ELP mais espesso em relação ao tendão do músculo ECP, no entanto em algumas das observações, a espessura entre eles foi exageradamente desproporcional (fig. 10). Em alguns casos tinham a mesma espessura, porém não evidenciamos em nenhuma de nossas preparações o predomínio da espessura do tendão ECP em relação ao tendão do ELP. A assimetria entre os antímeros foi registrada em 13 casos $(21,6 \%)$.

\section{DISCUSSÃO}

Diferentemente do que encontramos em relação ao músculo ECP, não evidenciamos em nenhuma de nossas preparações a ausência do músculo ou tendão do ELP. Zadek ${ }^{(15)}$ encontrou um caso em que ocorreu a ausência congênita bilateral do ELP, refere que não encontrou descrição semelhante na literatura. Porém anteriormente, Pearson e Robinson ${ }^{(10)}$ dissecando 131 membros já haviam verificado por duas vezes $(1,5 \%)$ a ausência do músculo ELP. Posteriormente, alguns autores ${ }^{(7,9,14)}$ também anotaram a ausência desse tendão sem se referir no entanto, qual a freqüência dessa ocorrência.

Com referência à duplicação do tendão do músculo ELP relatada por alguns autores ${ }^{(8,11,13)}$, encontramos em três de nossas observa-

\section{DISCUSSION}

Differently from what was found in relation to the EPB muscle, we did not see in any of the preparations the absence of the muscle or tendon of the EPL. Zadek ${ }^{(15)}$ found a case where there was the bilateral congenital absence of the EPL, he reported he did not find any similar description in the literature. However, previously, Pearson \& Robinson ${ }^{(10)}$ while dissecting 131 upper and lower limbs had already checked them twice (1,5\%) the absence of the EPL muscle. Later, some authors ${ }^{(7,9,14)}$ also noted the absence of this tendon, however without referring the frequency of this occurrence.

About the duplication of the tendon the EPL muscle reported by some authors (8,11,13), we found among 3 of our observations $(4,8 \%)$, one bilateral, in these cases the tendon duplicated after passing through the third osteofibrosesr compartment, joining again some centimeters proximally to the metacarpophalangeal joint.

The existence of the EPL accessory muscle described at the beginning by Kaplan(6), was recently reported by other authors ${ }^{(1,2,4,13)}$, however the description about the way and insertion of the accessory muscle differ from the authors. Kaplan describes that this accessory muscle is located between the EPL and the extensor of the index finger originating a double tendon one which goes to the thumb and the other to the index finger. Abu-Huleh ${ }^{(1)}$ states that accessory muscle, which he found in a male human cadaver dissection, originated from the ulna passing through the fourth osteofibroses compartment together with the common extensors of the fingers and the own index finger, going to the thumb and insert itself at the base of the proximal phalanx Cohen \& Haber(4) reported they found a muscle having accessory tendon also passing through the fourth extensor canal, however with a different insertion at the base of distal phalanx of thumb.

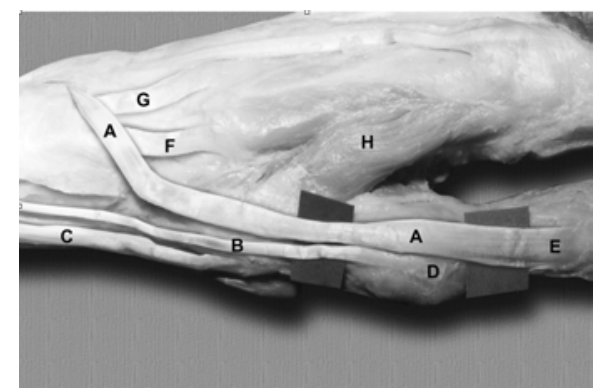

Figura 1 - O tendão do músculo $\operatorname{ELP}(A)$

apresenta uma variação anatômica em seu trajeto. Ao passar pelo terceiro

compartimento osteofibroso inclina-se para o lado radial acompanhando os tendões ECP

(B) e $A L P(C)$ não formando a clássica

tabaqueira anatômica. BFP (D). BFD (E). tendões ERLC (F) e ERCC (G). Primeiro ID (H).

Figure 1 - The tendon of EPL muscle (A) shows an anatomical variation in its trajectory. When passing by the third osteofibroses compartment it bents to the radial side following the EPB $(B)$ and $A P L(C)$ tendons without forming the classical anatomical shape BFP (D) BFD (E) tendons ERLC (F) and ERBC (G). First DI (H).

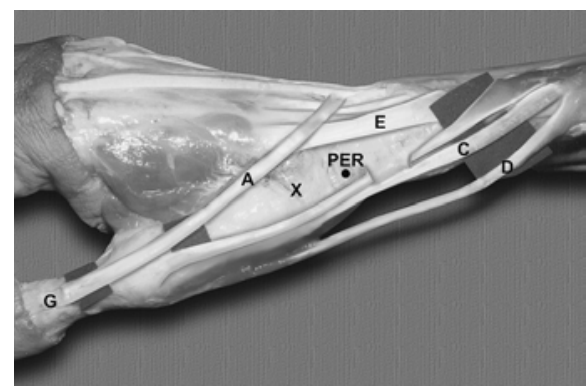

Figura 2 - Conformação anatômica normal. $O$ tendão $E L P(A)$ formando a tabaqueira anatômica $(X)$ com os tendões $E C P(B)$ e $A L P(C$ e D). ERLC (E), Processo estilóide do rádio (PER). $B F D(G)$.

Figure 2 - Normal anatomical conformation The EPL $(A)$ tendon forming the anatomical shape $(X)$ with the ECB $(B)$ and $A P L$ ( $C$ and $D)$ tendons. Styloid process of radius (SPR). $B F D(G)$.

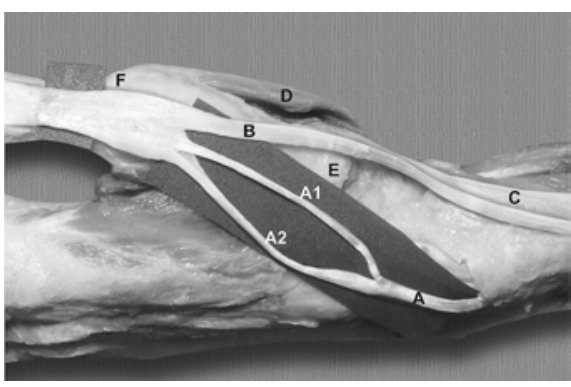

Figura 3 - Distalmente ao terceiro compartimento osteofibroso, observamos a duplicação (A1 e A2) do tendão do ELP (A) voltando a se unir proximalmente a AMFP $(F)$. Tendão ECP (B). Músculo ACP (D). BPM (base do primeiro metacarpiano) (E). Tendão do $A L P(C)$. inserem-se na BFP $(E)$ e as laterais (C1 e D1) na BFD (F). Tendão ALP (G). BPM (H). Músculo ACP (I). Tendões $\operatorname{ERCC}(\mathrm{J})$ e $E R L C(K)$.

Figure 3 - Distally to the third osteofibroses compartment, a duplication of (A1 and A2) of the EPL $(A)$ tendons joining proximally to the AMFP $(F)$ again. EPP $(B)$ tendon. APB $(D)$

muscle. BFM (the base of the first metacarpal) (E). APL (C) tendon. Insert themselves in the BPP $(E)$ and Laterals of (C1 and D1) in the BPD (F). The APL (G) tendon. BPM $(H)$. The APB (I) muscle. ERBC $(J)$ and $E R L C(K)$ tendons. 


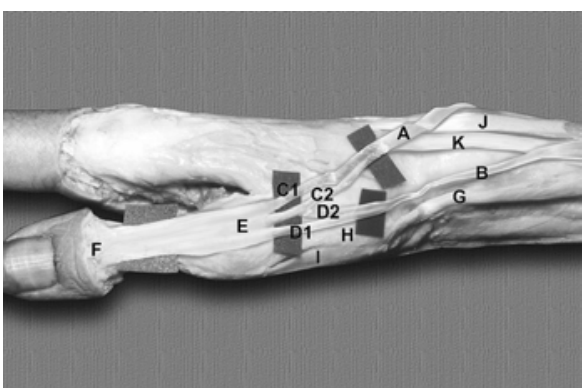

Figura 4 - Duplicação dos tendões dos músculos $\operatorname{ELP}(A)$ em (C1 e C2) e ECP (B) em

(D1 e D2) proximal a AMFP. As divisões centrais (C2 e D2)

Figure 4 - The duplication of the $E L P(A)$ in (C! and C2) tendons muscles and EPB (B) in

(D1 and D2) proximal to AMP. The central division of (C2 and D2).

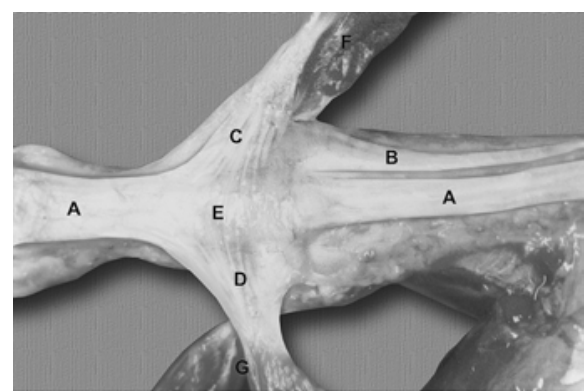

Figura 5 - Aparelho extensor do polegar. Tendão do ELP. Tendão do ECP (B). As fibras aponeuróticas $(C$ e $D)$ do $A C P(F)$ e músculo adutor do polegar $(G)$ inserindo-se nos tendões ELP e ECP. BFP (E).

Figure 5 - thumb extensor apparatus . EPL tendon. $E P C(B)$ tendon. ( $C$ and $D$ ) apneurotics fibers and $(G)$ abductor thumb muscle inserting ithself to the EPL and EPB tendons. BPP (E).

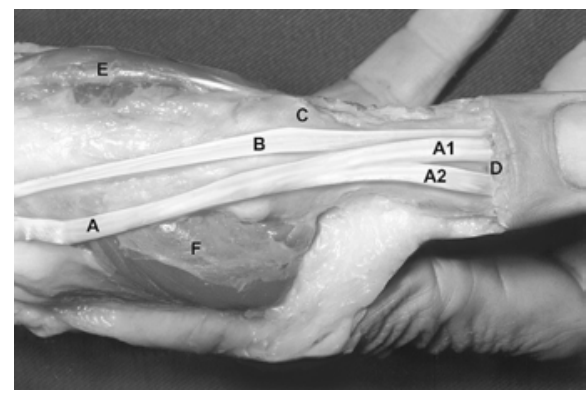

Figura 8 - Duplicação do tendão $E L P(A)$ em (A1 e A2) distal a AMFP (C). Tendão do ECP $(B)$ estendendo sua inserção até a BFD (D). Músculo $A C P(E)$. Músculo primeiro ID $(F)$.

Figure 8 - The duplication of the EPL (A) tendon in (A1 and A2) distal to AMP (c). EPB (B) tendon extended its insertion till the BFD (D). $A P B(E)$ muscle ID (F) first muscle.

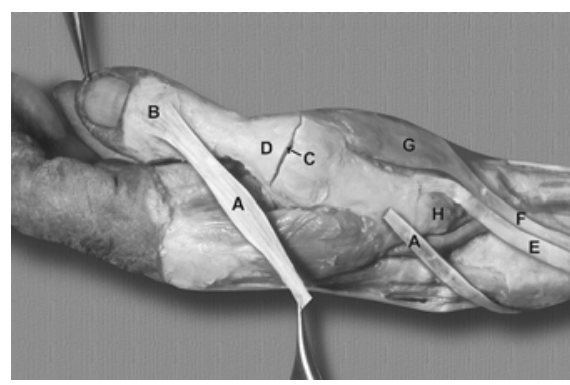

Figura 6 - Não foi registrada a inserção do tendão $\operatorname{ELP}(A)$ na BFP $(D)$. Nota-se a inserção óssea de $(A)$ na $B F D(B)$. Tendões do ALP (E e F). Músculo ACP (G). BPM (H). $A M F(C)$.

Figure 6 - The insertion of EPL $(A)$ in the $B P P(D)$ was not recorded. It is noticeable the (a) bone insertion in the BPD A) in the $B P D(B)$. The APL(E and F) tendons. APB (G) muscle. BFM(H). AMP (C).

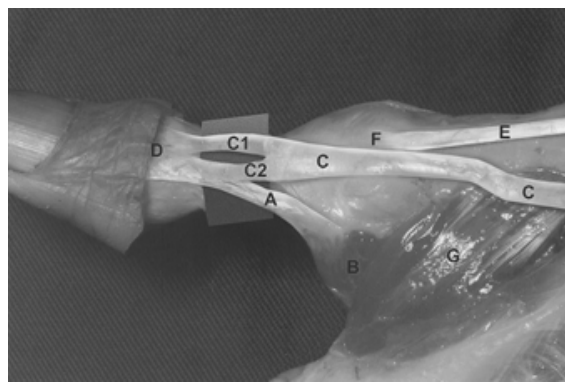

Figura 9 - Nota-se a existência de um vínculo tendinoso unindo o músculo adutor do polegar (B) ao tendão do ELP (C). Duplicação de (C) em (C1 e C2) distal a AMFP. BFD (D). BFP (F). Tendão ECP (E). Primeiro ID (G).

Figure 9 - a tendinous link existence is seen joining the abductor pollicis muscle $(B)$ to the ELP (C) tendon. Duplication od (C) into (C1 and C2) distal to AMP. BFD (D). BPP (F). $E P B(E)$ tendon. First ID (G).

Figure 7 - The EPB $(B)$ tendon muscle, in this observation its insertion extended itself till $B P D(C)$. EPL $(A)$ with its normal insertion in $B P D(C)$. The $E R L C(D)$ and ERBC (E) tendon. $B F M(F)$. BPP (G). First ID (dorsal interbone) (H). BSM (the base of the second metacarpal) (I) BTM (the base of third metacarpal) (J).

ções $(4,8 \%)$, sendo uma bilateral, e nestes casos o tendão se duplicava após a passagem pelo terceiro compartimento osteofibroso, voltando a se unir alguns centímetros proximalmente a articulação metacarpofalângica.

A existência de um músculo ELP acessório, descrita inicialmente por Kaplan ${ }^{(6)}$, foi recentemente relatada por outros autores ${ }^{(1,2,4,13)}$, porém as descrições sobre o trajeto e inserção do músculo acessório diferem entre os autores. Kaplan ${ }^{(6)}$ descreve que esse músculo acessório localiza-se entre o ELP e os extensores do indicador dando origem a um duplo tendão que se destina para o polegar e o outro para o indicador. Abu-Hyleh ${ }^{(1)}$ afirma que o músculo acessório, que encontrou na dissecção de um cadáver do sexo masculino, originavase na ulna passando pelo quarto compartimento osteofibroso junta-
Beatty et al.(2) found an accessory tendon of the EPL while making a surgery, however they refer that it was not possible to identify the local of this tendon insertion, but they noticed that after the removing of this accessory tendon relieved the severe pains the patient had. During the surgery, however in 1998, made by our staff, was found an accessory tendon placed between the EPL and the extensors of the index fingers, which originated a double tendon, and this corresponds to the description made by Kaplan ${ }^{(6)}$. In this case, the double tendon also drove itself to the thumb and index finger; nevertheless it joined each other to the tendon of the EPL muscle and to the tendon of the common extensors fingers muscles which drove to the index finger.

We did not find the presence of the accessory tendons during our 
mente com os extensores comuns dos dedos e próprio do indicador, dirigindo-se ao polegar e inserindo-se na base de sua falange proximal. Cohen e Haber ${ }^{(4)}$ relatam que encontraram um músculo com o tendão acessório também passando pelo quarto canal extensor, porém com inserção diferente na base da falange distal do polegar. Beatty et al.(2) encontraram um tendão acessório do ELP em um ato cirúrgico, porém referem que não foi possível identificar o local da inserção desse tendão, referem que a remoção desse tendão acessório aliviou as fortes dores que o paciente apresentava. Durante um ato cirúrgico em 1998, realizado pela nossa equipe, foi encontrado um tendão acessório localizado entre o ELP e os extensores do indicador, o qual dava origem a um duplo tendão, o que corresponde exatamente à descrição feita por Kaplan ${ }^{(6)}$. Nesse caso, o duplo tendão também se dirigia ao polegar e ao indicador, porém unia-se ao tendão do músculo ELP e ao tendão do músculo extensor comum dos dedos que se dirigia para o indicador.

Não encontramos a presença de tendões extensores acessórios em nossas dissecções, como também não encontramos uma expansão tendinosa proveniente do extensor comum dos dedos que atuava como um reforço para o ELP, conforme descreveram Poirier e Charpy ${ }^{(11)}$ e Testut e Latarjet ${ }^{(13)}$.

Kaplan(6) também afirma que em algumas situações o tendão do músculo ELP pode ter menor calibre que o do ECP. Em nossas dissecções esse fato não foi verificado, pois sempre encontramos o tendão do ELP com o calibre semelhante ou na grande maioria das vezes tendo maior calibre que o ECP. Nossos resultados mostram que em alguns casos a diferença de calibre chega a ser desproporcional, como pode ser observado na figura 10. Em nosso laboratório ${ }^{(3)}$ foi encontrado bilateralmente em um cadáver, uma variação no trajeto do tendão do ELP em que, após passar por seu túnel osteofibroso, dirigia-se em direção radial quase em ângulo reto em relação ao seu trajeto no antebraço, seguindo junto com os tendões do ALP e ECP de modo a não formar a tabaqueira anatômica; refere que neste caso o tendão do ECP estava ausente. Encontramos variação semelhante em uma de nossas dissecações, sendo que nesse caso, o tendão do músculo ECP estava presente.

Em uma peça anatômica correspondente à mão direita de um cadáver, o tendão do músculo ELP duplicava-se $3 \mathrm{~cm}$ proximal à articulação metacarpofalângica, o mesmo ocorrendo com o tendão do músculo ECP. Os componentes dos dois tendões que se dirigiam ao centro da articulação uniam-se e inseriam-se ao nível da articulação metacarpofalângica. Os dois componentes laterais cruzavam a articulação metacarpofalângica e se dirigiam para inserir na base da falange distal. Afirmamos que não encontramos relatos de arranjos anatômicos semelhantes a esses na literatura pesquisada. A figura 4 demonstra essa variação anatômica.

A inserção do tendão do ELP na cápsula articular da articulação metacarpofalângica foi verificada em 14 casos, porém não verificamos a inserção óssea na base da falange proximal em nenhum dos nossos casos. Em cinco mãos (duas bilateralmente) encontramos a duplicação do ELP, distalmente à articulação metacarpofalângica, e os dois componentes inseriam-se na base da falange distal, registrado na figura 8. Em três peças anatômicas, todas unilateralmente encontramos a existência de um vínculo tendinoso unindo os tendões dos músculos adutor do polegar ao tendão do ELP próximo à sua dissections, neither found tendinuous expansion from the common extensor fingers which acted with effort to the EPL, according to Poirier \& Charpy ${ }^{(11)}$ e Testut \& Latarjet ${ }^{(13)}$

$K_{\text {Kaplan }}^{(6)}$ also states in some situations the EPL muscle may have shorter caliber than the $E P B$. During the dissection this fact was not checked, because we normally found the EPL with a normal calibre or most of the time having bigger calibre than the EPB. The results showed that in some cases the difference of size can be disproportional, as it can be seen in the figure10. It was found in our laboratory ${ }^{(3)}$ bilaterally in a human cadaver, a variation in the trajectory of the tendon of EPB that after passing through a osteofibroses tunnel, drove towards the radial direction almost in a straight angle in relation to its trajectory of the forearm, following together with the tendons APL and EPB in order to form the anatomical shape: it means that in this case the tendon of the EPB was absent. We found similar variation in one of the dissections, and in this case the tendon EPB muscle was there.

In an anatomical piece corresponding to the left hand of a human cadaver, the tendon EPL muscle duplicated 3 centimeters proximal to the metacarpophalangeal joint, the same happening with the tendon EPB. The components of the two tendons which drove to the center of the joint and inserted themselves till the level of the metacarpophalangeal joint, the two lateral components crossed the metacarpophalangeal joint and drove in order to insert in the base of distal phalanx. We state we did not find reports about anatomical arrangements similar to these ones in the researched literature. The figure 4 shows the anatomical variation. The insertion of the tendon $E P L$ in the joint capsule of the metacarpophalangeal joint verified in 14 cases, however we did not check the bone insertion at the base of proximal phalanx in any of the cases. In five hands (two bilateral) we found the duplication of the EPL, distally to the metacarpophalangeal joint, and the two components insert themselves into the base of distal phalanx, recorded at figure 8. among three anatomical pieces, all unilaterally we found the existence of a tendinuous bound joining the tendons of abductor pollicis to the tendon EPL next to its insertion at the base of distal phalanx, showed in figure 9. Kaplan ${ }^{(6)}$ states that the insertion of the abductor and APB in the extensor device may happen in a variable way. Therefore we can consider these bindings as making part of these variations.

Ledouble ${ }^{(8)}$ described a case that the tendon EPL muscle, in addition of inserting itself in the first and second phalanx, it also inserted itself in the scaphoid. We did not report a similar case in the dissection work.

Stein ${ }^{(12)}$ found asymmetry between the right and left antimeres in three of 42 human cadavers $(7,1 \%)$ e Caetano ${ }^{(3)}$ only once among 30 dissected human cadavers (3,2\%). We verified asymmetry in 12 among 30 cadavers $(35,2 \%)$ This disagreement can be explained differently from the authors cited above, the most important objective of this study was the distal tendon insertion, therefore any variation of insertion between the antimeres was classified as asymmetric.

\section{CONCLUSION}

The tendon bone insertion of the tendon EPL at the base of distal phalanx was recorded in all observations (100\%). While passing through the metacarpophalangeal joint an insertion in the capsule of this joint 
inserção na base da falange distal, mostrado na figura 9. Kaplan(6) afirma que a inserção do adutor e ACP no aparelho extensor pode ocorrer de maneira variável. Podemos então considerar esses vínculos como fazendo parte dessas variações.

Le Double(8) descreveu em caso, em que o tendão do músculo ELP, além de se inserir nas primeira e segunda falanges, inseria-se também no escafóide. Não registramos caso semelhante em nossas dissecações.

Stein ${ }^{(12)}$ encontrou assimetria entre os antímeros em 3 de 42 cadáveres $(7,1 \%)$ e Caetano ${ }^{(3)}$ apenas uma vez em 30 cadáveres dissecados $(3,2 \%)$. Verificamos assimetria em 12 de 30 cadáveres $(35,2 \%)$. Essa discordância pode ser explicada pelo fato de que diferentemente dos autores acima, o objetivo maior de nosso estudo foi a inserção distal do tendão, portanto qualquer variação de inserção entre os antímeros foi considerada como assimetria.

\section{CONCLUSÕES}

A inserção óssea do tendão do músculo ELP na base da falange distal foi registrada em todas as observações (100\%). Durante sua passagem pela articulação metacarpofalângica foi verificada a inserção na cápsula dessa articulação em 14 mãos (23,3\%), porém nenhuma inserção óssea nesse local.

O padrão anatômico em relação à inserção do tendão ELP que sugerimos também que seja considerado como normal, foi a presença de um tendão único inserindo-se por meio de uma inserção óssea na base da falange distal do polegar.

\section{REFERÊNCIAS BIBLIOGRÁFICAS}

1 - Abu-Higleh MF. Extensor pollicis tertius: an additional extensor muscle of the thumb. Plast Reconst Surg 92:340-343, 1993

2 - Beatty JD, Remedius D, Mc Cullough CJ. An acessory extensor of the thumb as a cause of dorsal wrist pain. J Hand Surg 25:110-111, 2000

3 - Caetano EB. Contribuição ao estudo anatômico e funcional dos músculos do polegar. [Dissertação]. São Paulo, 1981. Centro de Ciências Médicas e Biológicas - Sorocaba, PUC-SP .

4 - Cohen BE, Haber JL. Supernumerary extensor tendons of the thumb: a case report. Ann Plast Surg 36:105-107, 1996

5 - Hollinshead WH. Anatomy for surgeons. New York, Hoeber Harper, 1958. p.393-394

6 - Kaplan EB. Anatomia funcional y quirurgica de la mano. Buenos Aires, Artecnica, 1961. p.101-143.

7 - Kobayashi A, Ohmiya K, Iwakuma T, Mitsuyasu M. Unusual congenital anomalies of the thumb extensors. Report of two cases. Hand 8: 17-21, 1976

8 - Le Double AF. Traité des variations do système musculaire de l'homme. Paris, Schleicher, 1897. p.103-171. was seen in 14 hands (23,3\%), however any bone insertion in this area was seen.

The anatomical pattern in relation to the tendon EPL insertion we suggest it to be considered as normal, it was the presence of an unique tendon insert itself through a bone insertion at the base of distal pollicis phalanx.
9 - McMurtry RY, Jochims JL. Congenital deficiency of the extrinsic extensor mechanism of the hand. Clin Orthop 125:36-39, 1977.

10 - Pearsons FG, Robinson A. Eight report of the Committee of Collective Investigation of the Anatomical Society of Great Britain and Ireland for the year 1897-98. J Anat Physiol 33:189-192, 1898.

11 - Poirier PS, Charpy A. Traité d'anatomie humaine. 2 ed. Paris, Masson, 1912 p.433-470.

12 - Stein $\mathrm{AH}$. Variations of tendon of insertion of the abductor pollicis longus and extensor pollicis brevis. Anat Rec 110:49-55, 1951.

13 - Testut L, Latarjet A. Tratado de anatomia humana. $8^{a}$ ed. Barcelona, Salvat 1947. p.1059-1086.

14 - Tsuge K. Congenital aplasia or hypoplasia of the finger extensors. Hand $7: 15-21,1975$

15 - Zadek I. Congenital absence of the extensor pollicis longus of both thumbs. Operation and cure. J Bone Joint Surg 16:432-434, 1934 